\title{
Recreating Historical Malay Architecture with BIM Process
}

\author{
Muhammad Hadi Mustafa \\ Department of Quantity Surveying, Kuliyyah of Architecture and Environmental Design, International Islamic University Malaysia, 53100, \\ Gombak, Selangor
}

Maisarah Ali

Department of Civil Engineering, Kuliyyah of Engineering, International Islamic University Malaysia, 53100, Gombak, Selangor

Khairusy Syakirin Has Yun Hashim and Mohamad Saifulnizam Mohd Suhaimi

Department of Quantity Surveying, Kuliyyah of Architecture and Environmental Design, International Islamic University Malaysia, 53100, Gombak, Selangor

\begin{abstract}
In South-East Asia, the Malay architecture is among the popular subject of research because of its historical importance within the region, apart from many others. To some researchers, the Malay architecture is unique because of its intangible meaning and historically rich design characters. It is difficult to be reproduced, and only limited numbers of people are acknowledged as experts. With the introduction of technology such as BIM, it is hypothesized that the gap can be minimized. The idea of this paper is to outline the process of recreating cultural architectural design using a modern process such as Building Information Modelling (BIM) platform in specific, from data collection using Terrestrial Laser Scanning (TLS) and digitalization process in Revit software. This paper employs observation approach using data from laser scanner collected from case study and content analysis technique. While normally most of the cultural architecture is undocumented, the findings of this activity are aimed to provide guideline to develop geometrical information for heritage-enthusiast in practicing their undertakings. It is hoped that more historical and cultural architecture can be recreated and appreciated for the use and inspiration of current construction industry.
\end{abstract}

\section{Article History}

Received : 29 November 2019

Received in revised form : 4 February 2020

Accepted : 7 March 2020

Published Online : 30 April 2020

\section{Keywords:}

HBIM, malay architecture, terrestrial laser scanning, case study, process

\section{Corresponding Author Contact:}

maisarah@iium.edu.my

DOI: $10.11113 /$ ijbes.v7.n2.504

C 2020Penerbit UTM Press. All rights reserved

\section{Introduction}

Across the world, the rate of decline and disappearance of historical buildings such as wooden traditional Malay houses in the Malay archipelago, churches in the European countries, castles in Japan and China or even mosques in the Middle East is accelerating. Designs on historical building are often intricate and difficult to reproduce, even by experts. Up until recent years, the re-production of as-built drawing for historic buildings are often being done by hand measuring, which is very tedious and timeconsuming (Foxe,2010). At the end of the activity, most people are left with inaccurate and incomplete data because of unavoidable factors such as financial and time constraints. With the introduction of laser scanner, a highly accurate threedimensional model of the complete interior and exterior of any building can be created in a shorter time (Pesci et al., 2012) Using the data, it is possible then to use any BIM software such as Autodesk Revit to reproduce the plans, elevations and sections of the designs and buildings. These documents can then be used as references for recreating the architectural design. Therefore, this paper intends to outline the process of recreating cultural architectural design using a modern process such as Building Information Modelling platform in specific, from data collection 
using Terrestrial Laser Scanning (TLS) and digitalization process in Revit software.

\subsection{Historical Buildings and Styles of Malay architecture in Peninsular Malaysia}

The Ministry of Cultural, Art and Heritage defined historical buildings as tangible heritage under the static category, which consists of monuments and buildings such as palaces, fortress, tombs, and towers. Any building which is more than 50 years of age and gazetted by the Department of National Heritage can be considered as heritage building whereas non-gazetted building is considered historical building. Fielden (2003) defined a historic building as any building that could give an impression and make a person curious about the race and culture that built them. He also said all buildings over 100 years old should be deemed historic buildings. In brief, a historic building can be described as a building that can depict particular values such as its history, architecture, symbolism, and feelings to local individuals.

The styles of Malay architecture in Peninsular Malaysia were comprised of many typologies such as buildings for administration, institutions, religious buildings, homes, and many more. Most of the buildings are beautifully decorated and have distinctive designs that are not found in most present buildings. Among historical buildings that exist in Peninsular Malaysia are shown in Table 1. These historic cultural buildings should be properly conserved and preserved as these national treasures are irreplaceable to our nation. Failure to manage and preserve these historic buildings can have a detrimental impact on our nation. This is because owing to any poor decisions or actions, a century of wealthy history that could be translated from a building can be destroyed by a split second. It can be seen nowadays that historical buildings such as shophouses, townhouses, and traditional Malay houses are now fighting for survival owing to factors such as demolition, neglect, and lack of effort to preserve them. According to Akadiri et al. (2012), damages that occur to building indirectly will affect their structural integrity and its fabric. It will also affect the façade, which gives negative impacts for tourism sectors, and it will eventually also give negative impression towards the conservation industry in Malaysia (Harun,2011). Historical buildings are prone to damages owing to many factors, and the damage must be correctly resolved according to conservation principles, philosophy, and ethics. All historic buildings must be continually preserved, not only when damage is noticeable. Regular check-ups should be performed, and adequate monitoring through technology such as BIM can be helpful.

\subsection{Digitalization Using Laser Scanner: Scan-to BIM}

Global trends are making AEC projects more complex, while advances in technology are helping industry professionals work more efficiently and effectively. The power of BIM is how it allows architects, engineers, and contractors to collaborate on coordinated models, giving everyone better insight into how their work fits into the overall project, ultimately helping them to work more efficiently. Traditionally, buildings have been documented by sending a team out into the field where the teams take measurement to their nearest centimetres or inch and produce hand-drawn drawings, which can take a long time to produce. Instead, a site can be scanned in a matter of hours or days and plans can be studied from those scans (Ali et al., 2018).

The BIM is increasingly being accepted and practiced in most part of the world; whether to assist in designing a project or to develop an operating system in constructing a building efficiently. Other countries, including Finland, Singapore, Denmark and Norway, have also adopted BIM (Ali et al., 2018). However, in the Malaysian industry, Zahrizan et al. (2013) found that the adoption of BIM in Malaysia needs attention. They highlighted that "Due to the lack of knowledge of BIM and the low level of BIM uptake by the Malaysian construction players, the implementation of BIM in the Malaysian construction industry thus lies between BIM level 0 and BIM level 1. This statement is later supported by CIDB BIM Report 2016. It was mentioned that the adoption is still low because the Malaysian construction industry has very slow development in using the application of Information Communication Technology (ICT). The challenges are the unavailability of sufficient experts within the country, relevant equipment for practicing are scarce, limited availability of trainers, and financial-related challenges (Del Giudice \& Osello, 2013; Harun, 2011; Zahrizan et al., 2013; Abbasnejad \& Moud 2013). These challenges, however, should not prevent, or even discourage construction players from taking advantage of this technological advancement in different ways.

The low adoption in implementing BIM has caused losses to the current industry in Malaysia as the benefit of BIM does not only improve the technology itself; it also changes the process of design and builds (Kymmel, 2008; Maina, 2018). Through the implementation of BIM, any vital information like the design information can be prepared and evaluate at a much faster time; enabling any decision-making process related to the project can be done in a much easier and efficient way (Mustafa et al., 2018; Maina, 2018). Moreover, BIM also conveniences to the project 
Table 1 The example of different typologies of historical buildings that exist in Peninsular Malaysia

Sources: 1- Ministry of Agriculture and Agro-based Industry,

2- https://www.maisinggah.com/bangunan-bersejarah-di-malaysia/ 3-https://www.orangnogori.com

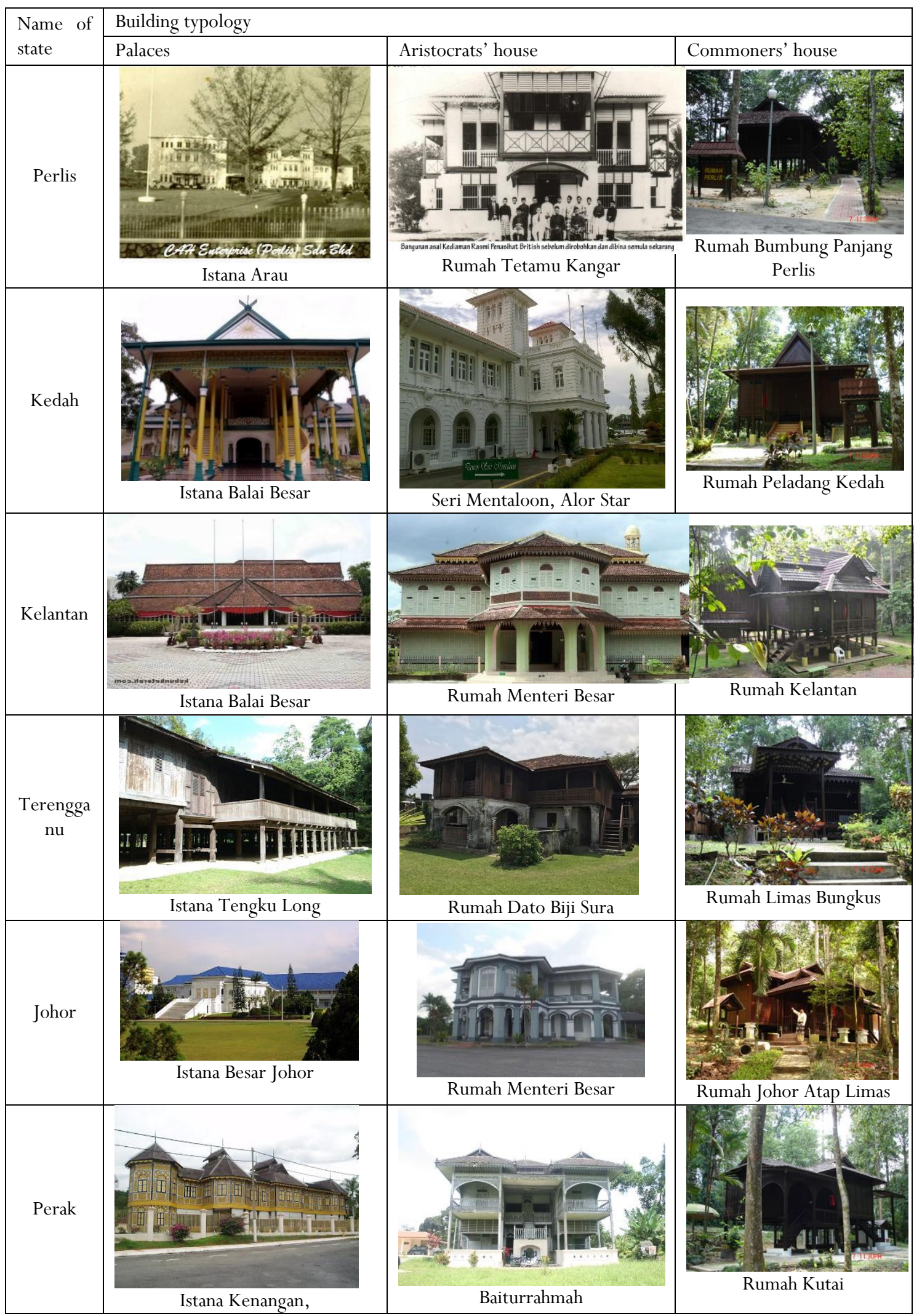




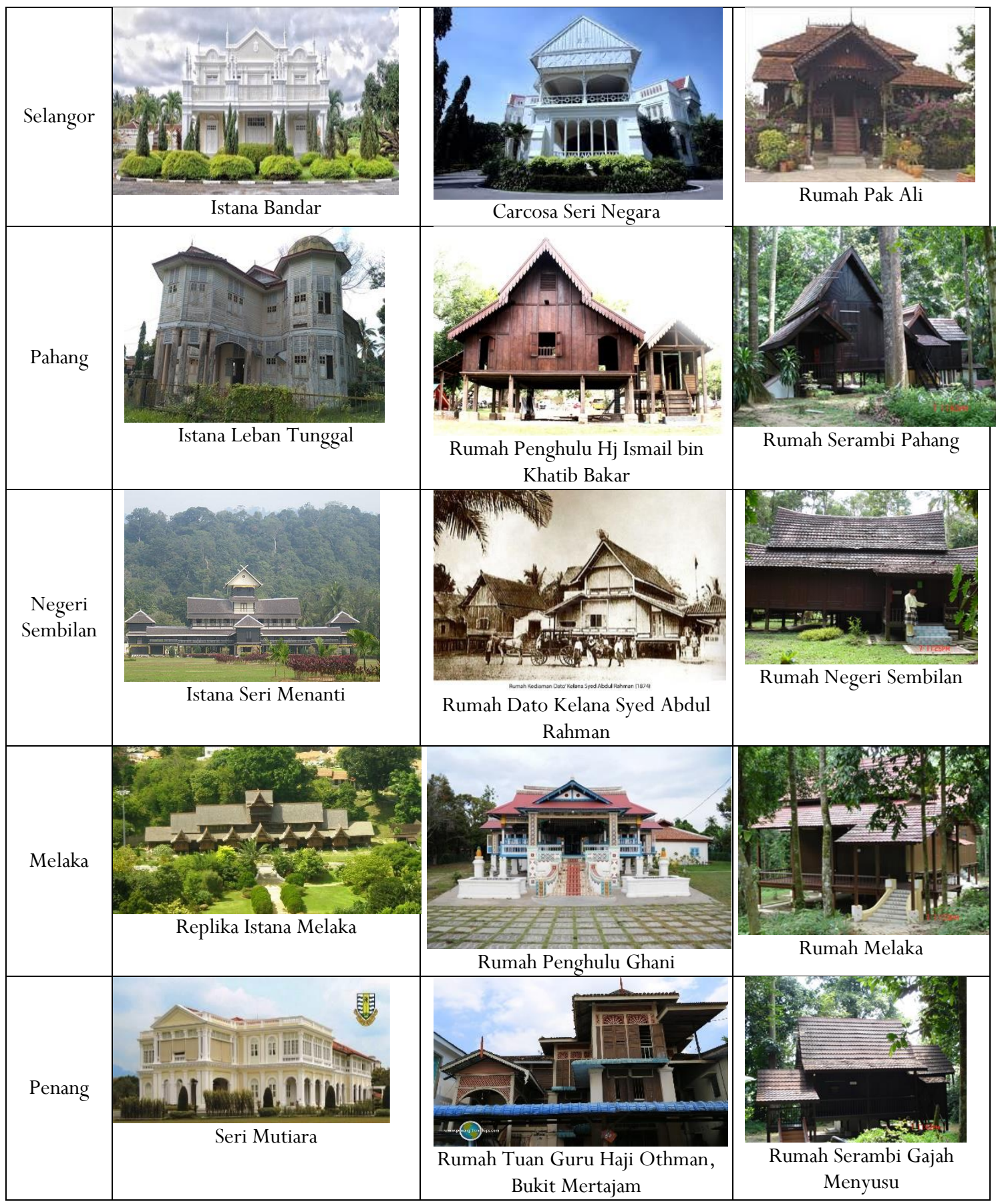


team to make any variation or changes to the project at any time along with the phase of work due to its parametric modelling capability (Autodesk, 2019). All the data needs to be formatted in the right way and available at the right time is not acting as barriers to its full adoption. BIM software makes up about onehalf of the components in the whole process.

BIM, however, has not been extensively applied to all aspects of a construction project (Mustafa et al., 2018; Seghier, Lim, Ahmad and Samuel, 2017). According to Kymmel (2008), the clearest benefit from BIM is that a 3D model improves the presentation ability in visualizing (understand) the model better. Many persons have difficulty understanding 2D drawing, and according to Maina (2018), there is an inadequate supply of qualified staff to meet specialised skills. While according to Eastman et al. (2008) and Rozana et al. (2018), the 3D model made by the BIM software is designed rather than generated from multiple $2 \mathrm{D}$ views. It is used to visualize the layout at any stage of the process expecting it will be consistent in every view.

Through virtual design and construction, BIM can provide an advantage to the Malaysian heritage industry by enhancing the cooperative level among various stakeholders. In the inspiration of 'renaissance' which means the revival of or renewed interest in something, clients will be able to have a wider range of design choices that reflects their cultural architecture (Autodesk, 2019; Ali et al., 2018). To achieve this, there is a need for a library of collected data on Malay architectural design to be made available, hence increasing the production efficiency and reduce the cost. Among data collection approach is by using a 3D laser scanner.

\subsection{Dimensional Laser Scanner}

The idea behind 3D laser scanning is LIDAR ( light detection and ranging ) and remote sensing. LiDAR is a remote sensing method that uses a laser to measure elevation and laser scanner works on the same principle (Quattrini et al. ,2015). Essentially, LIDAR is a beam of light that analyses the reflective light. The scanner then registers how long it takes for light to make its return, and using a set of an internal mirror and establishes horizontal and vertical angle by collecting point with correct $\mathrm{x} \mathrm{y}$ and $\mathrm{z}$ coordinates. The collection of points taken by a single scan will be recorded as point clouds (Baik, 2017).

\section{Methodology}

This paper employs observation approach using data from laser scanner collected from case study and content analysis. To achieve this, the research conducted an action-based research using a real case study and employs a qualitative approach in describing the findings. Observation has been used as a method for collecting data about people, processes, or even cultures (Kawulich, 2012).

\subsection{Selection of Case Study: Istana Balai Besar Alor Setar}

Digitalizing historic Malay building is different from other buildings because of its unique characters. Its architecture has a blend of influences which has created its unique building forms (Endut, 1993). In this paper, a more complex building such as the 'Istana' (palace) will be studied as compared to traditional Malay house because it can provide more data as compared to the latter which is too simple. This is also because Istana also carries more significance as compared to the normal cultural house because more historic events take place there.

According to a report from Kedah's state Archive retrieved by researchers on July 2018, The Grand Palace (Istana Balai Besar) is a unique hall which was built in 1735 by order of Sultan Muhammad Jiwa Zainal Adilin Muazzam Shah, the $19^{\text {th }}$ Sultan of Kedah (1710 - 1778). Its original function was to act as "Balai Penghadapan" for the king's official activities. The components were originally constructed from timbers, and after some incidents due to attacks from the Siamese (1821) and Bugis (1770), some part of the components were changed to steel and concrete. The building was re-constructed displaying the astonishing Malay's woodcarving at that time, and until now, its uniqueness still inspires many architect and tourists. This palace is among the oldest and the finest traditional Malay palaces which remains intact until today. However, it is subjected to the threats of natural decay, major flood and was once destroyed by fire, thus preserving its architectural and historical significance has become of paramount importance for posterity.

The process of reproducing the documentation comprises of two (2) main stages. The first stage is data collection on-site, where measurements need to be taken by the use of laser scanning technology. Laser scanning was selected as the technique of data collection because it is among the latest available measurement technology. The output from the laser scanner can be integrated with another technology such as BIM. In this research, 29 stations sites were used to capture data around the building, as shown in Figure 2. The second stage is the reconstruction of the building in the BIM platform, such as Autodesk Revit using the data collected from the laser scanning activity. In this study, Autodesk Revit was used because of the software's interface, which is user-friendly and easy to learn.

The scanner used is a TopCon GLS-2000. The specifications of the scanner are presented in Table 2. 
Table 2 The specification of the scanner used for the scanning activity

\begin{tabular}{|l|l|}
\hline $\begin{array}{l}\text { SCANNER/ } \\
\text { CHARACTERISTIC }\end{array}$ & Topcon GLS-2000 \\
\hline Laser Class & $3 \mathrm{R}$ and 1R \\
\hline Scanning method & Time of Flight \\
\hline Vertical field of view $\left(^{\circ}\right)$ & $270^{\circ}$ \\
\hline Horizontal field of view $\left(^{\circ}\right)$ & $360^{\circ}$ \\
\hline Range (m) and reflectivity & $\begin{array}{l}\text { Up to 350m; } 90 \% \text { reflectivity } \\
\text { (minimum range 0.4m) }\end{array}$ \\
\hline Scan Speed (pts/sec) & 120,000 points per/second \\
\hline 3D scanning accuracy & 3.5 mm at 150m \\
\hline $\begin{array}{l}\text { Camera(single image pixel } \\
\text { resolution) }\end{array}$ & 5 megapixels \\
\hline Processing software & JRC 3D RECONSTRUCTOR \\
\hline Tilting Sensor & Dual-axis compensator \\
\hline
\end{tabular}

\subsection{The Point Cloud Workflow On The Project}

Commissioning a point cloud is similar to a traditional 2D survey. It is only the deliverable that is different. The scan itself will render with intensity. Although point cloud is just discrete points, the density actually causes them to mimic a solid surface. However, because the laser only uses visible light, rather than infrared, it only records the surface it hits, rather than what is hidden behind the structure. Thus, it is important to acknowledge that laser scanning is a line-of-sight technology. Hence, because it only records whatever it hits, the users actually need to reposition the scanner around the site in order to capture the object all around (Quattrini et al.,2015). In this research, 29 stations sites were used to capture data around the building, as shown in Figure 1. However, most importantly, there must be an area of overlap between all of the sites. This can be done by using targets.

In order to create a complete point cloud, the scanner needs to be moved around both the inside and the outside of the building that is being scanned to fill in the missing areas. Before capturing the next scan, targets are placed in the direction where the scanner is moving. The main usage of the targets is to tie a scan location to the next. These targets will be used to automatically combine the multiple scans into a single data set of the complete as the as-built condition. Finally, once all the data was collected, they will be joined using ScanMaster software and forms a complete building as point clouds.

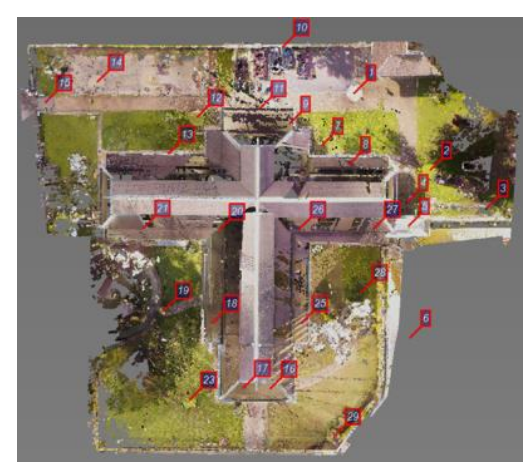

Figure 1: 29 scan stations are used during the data collection process (Authors, 2019)

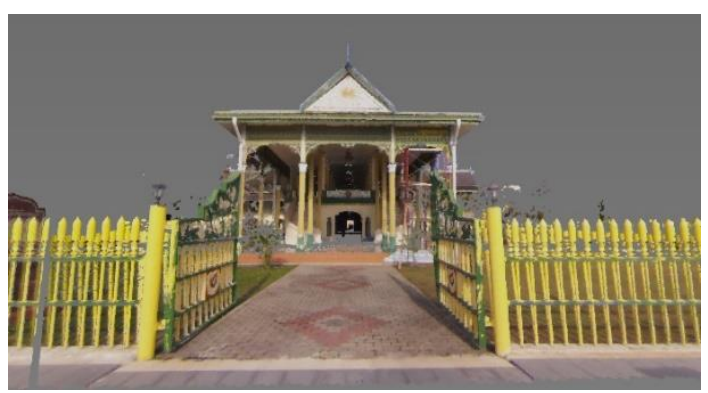

Figure 2: Istana Balai Besar frontage in point clouds (Authors, 2019)

After all of the scans have been registered using the targets in the field, the complete point cloud can be seen, as shown in Figure 2. Next, the point cloud can be exported to an application used in design such as Autodesk Reality Capture or also known as Autodesk Recap. Recap is a high-performance point cloud visualization engine that can be used to view and navigate the point cloud by cutting sections of the data. By having point clouds, it is possible to view the model in ways that would otherwise be difficult if using data collected with traditional means of as-built surveying and measuring (Quattrini et al., 2015).

In Recap, it is possible to look at the scan in a planar view by taking the sphere of data, unrolls it to look at the entire scan and manipulate the data. From this view, as shown in Figure 3, direct measurements can be taken by measuring from the layout, and the dimension is broken out to provide true measurement as our primary data. 


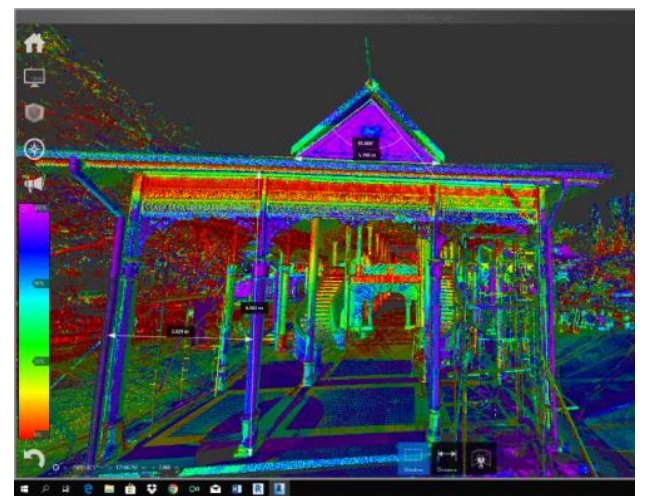

Figure 3: Measuring the dimension of building components can be carried out in the Recap platform (Authors, 2019)

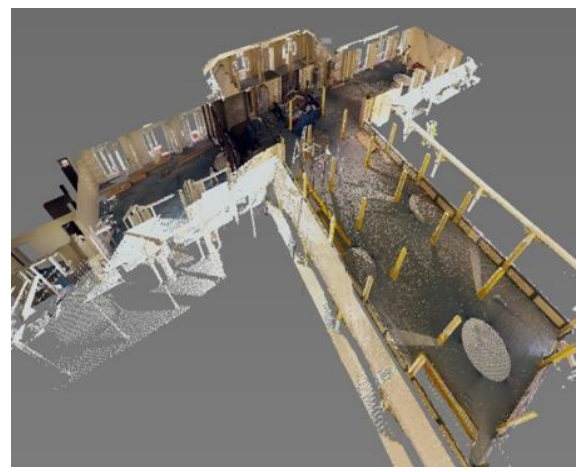

Figure 4: Cross-section of the building in point cloud (Authors, 2019)

In Figure 4, a cross-section of the building is made in order to view the floor to floor relationships and to determine the distance between the floors. By doing this, understanding of spaces within the building can be achieved (Abidin,1981) before modelling it in Revit. Measurement of the building also can be computed by point-to-point distance. For laser scanner TOPCON GLS-2000, the precision of measurement is up to $3.5 \mathrm{~mm}$.

Next, the point cloud is transferred into Autodesk Revit, where the point cloud is attached to a project as a link. After importing the point cloud, the plan section is cut all the way to the floor level so the floors' area can be clearly seen. From the floor plan, materials and finishes are recorded, and the building is modelled. As more information is needed for the modelling of the building, data from the point cloud in Recap is referred. The result in the form of as-built drawing is produced and presented.

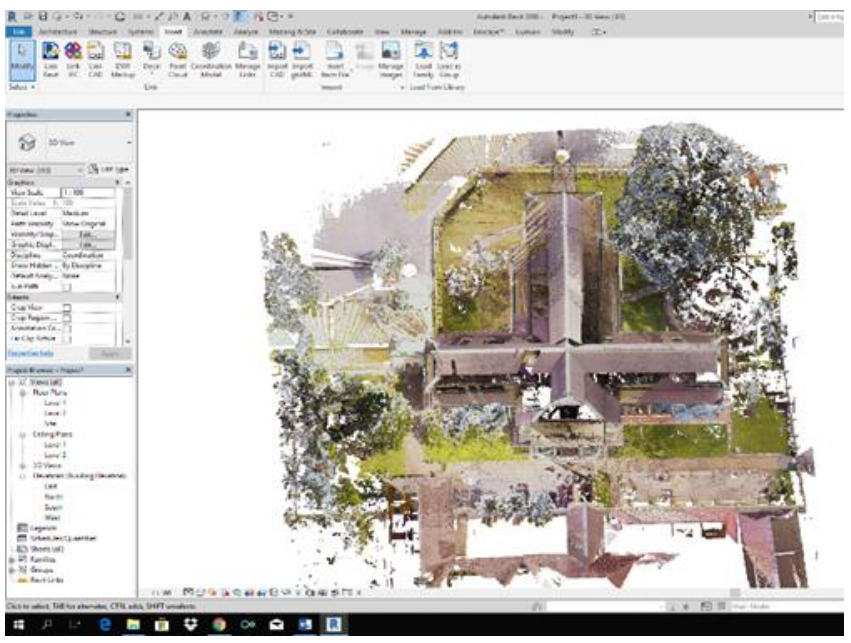

Figure 5: Point cloud in Revit (Authors, 2019)

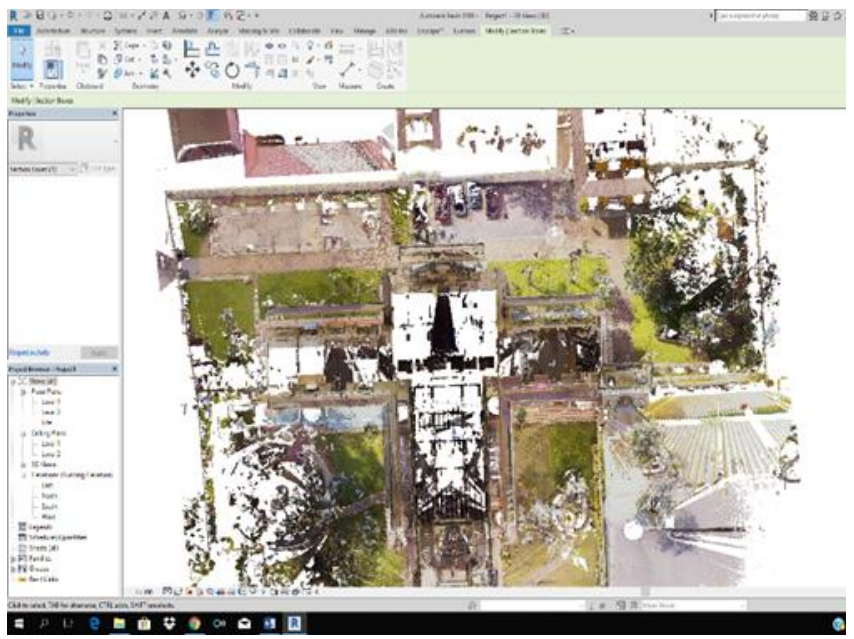

Figure 6: Layout floor plan of building (without roof) in Revit (Authors, 2019)

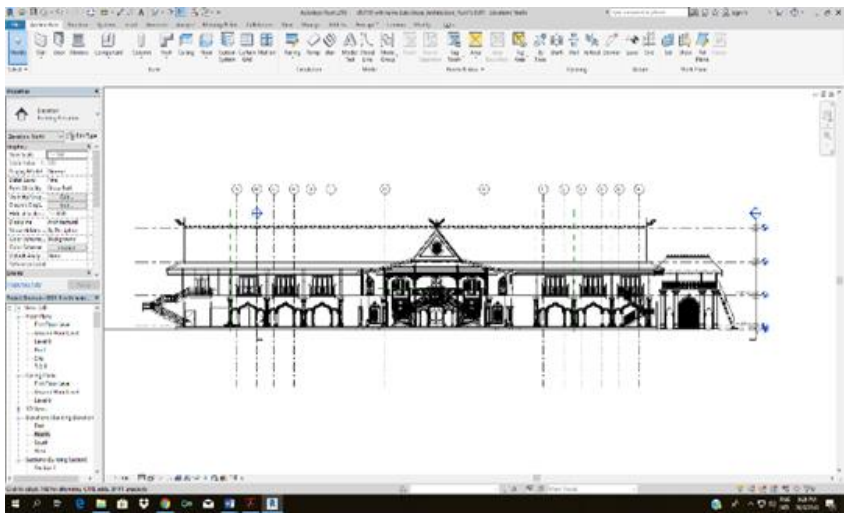

Figure 7: Positioning of Leica Terrestrial Laser Scanner P16 during scanning (Authors, 2019) 


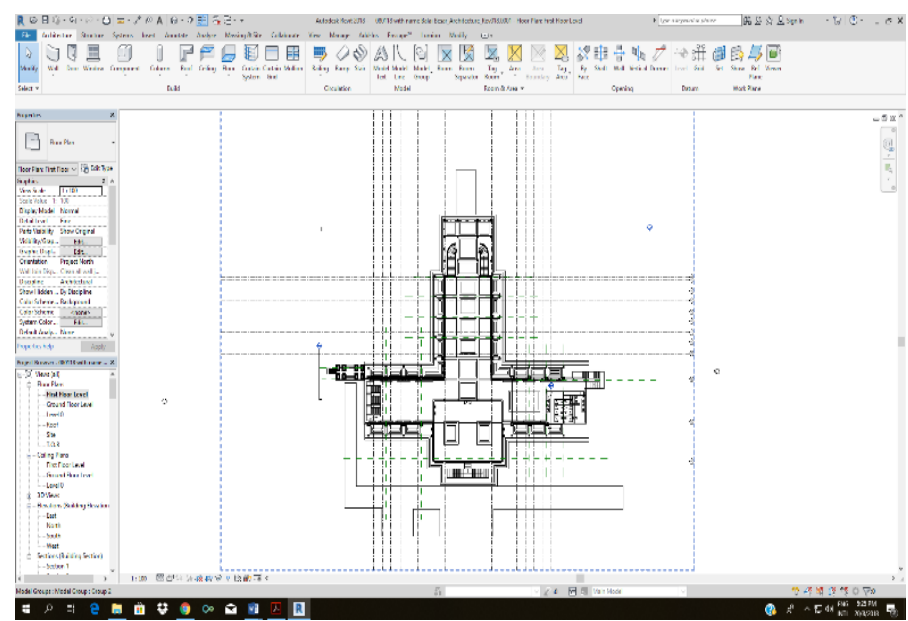

Figure 8: Building layout converted from point clouds to BIM using Revit (Authors, 2019)

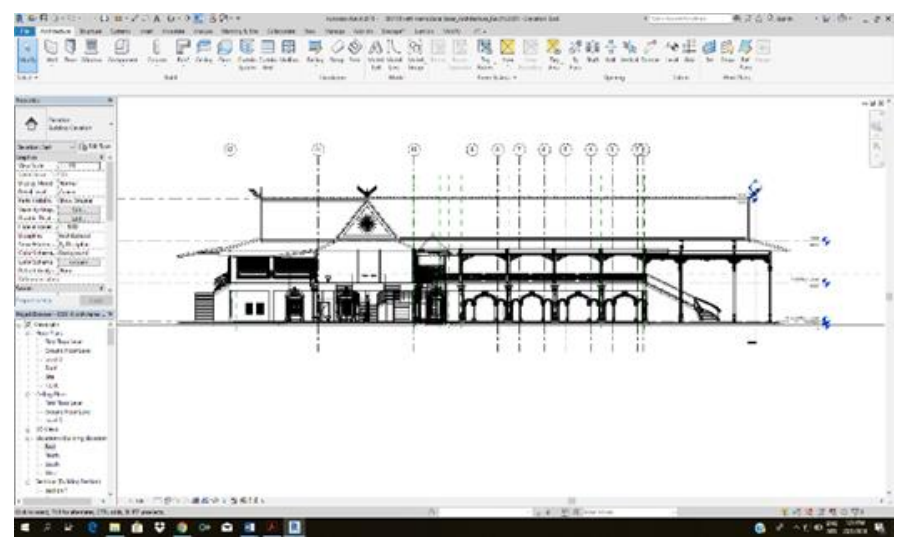

Figure 9: Building layout converted from point clouds to BIM using Revit in 3D view (Authors, 2019)

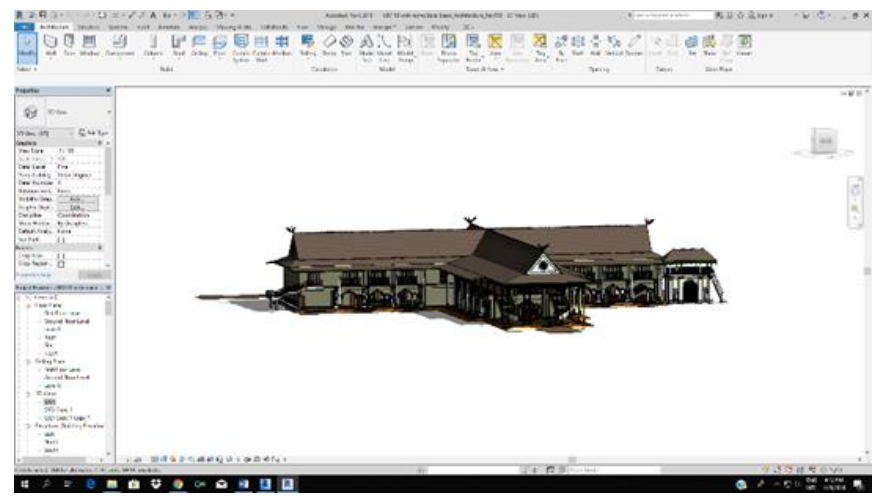

Figure 10: BIM model of Istana Balai Besar (Authors, 2019)
- Registration of data from TLS to produce .rcp file by using Cyclone 8.1 licensed software

\begin{tabular}{l|l}
\hline & $\begin{array}{l}\text {.rcp were opened in Recap and the size of file is } \\
\text { optimized by removing unnecessary areas } \\
\text { before modelling. }\end{array}$ \\
$\begin{array}{ll}\text { Point clouds are reduced in order to decrease } \\
\text { the size before exporting to Revit for } \\
\text { modelling. }\end{array}$ \\
$\begin{array}{ll}\text { - Unnecessary area of the point cloud must be } \\
\text { 'clipped/removed' in order to produce point } \\
\text { cloud that highlights on what is needed only. }\end{array}$ \\
\end{tabular}

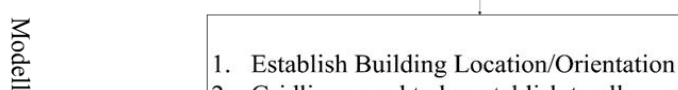

2. Gridlines need to be establish to allow easy modelling reference.

3. Check using the $3 \mathrm{D}$ view in point cloud on Revit.

4. Levels of the buildings must be established at sectional plan view.

5. Construct the wall accordingly.

6. Dimension and measurement can be taken from point cloud (.rcp) in Recap.

7. Locate and place relevant components accordingly to the point cloud data on the new Revit model.

8. Most of the time, the point clouds data must be hidden as it really slows down the modelling process. At interval, open it for double checking.

9. We also can focus on specific area by clipping in Recap. In such event, export .rcp again for the specific modelling of the area.

10. Color and properties of the components need to changed/ updated based on data collection.

11. Construct roof and change its properties accordingly.

12. The form, shape, and orientation the buildings should have been successfully produced as according to the size referred from point cloud (.rcp).

Figure 11: The process flow of digitalization using point clouds for Autodesk Revit(Authors' work)

\subsection{Digitalization Result and Analysis of Istana Balai Besar from Point Cloud Data}

One of the most useful aspects of BIM is that it can extract attributes data indicating, for example, the floor area of existing construction, or the variation of building components used for the building. Figures 5,6,7,8,9 and 10 are the results from the effort of modelling in BIM platform using the point clouds collected by laser scanning exercise meanwhile Figure 11 highlights the flow of digitalization using point clouds using Autodesk Revit. The asbuilt drawings of a traditional Malay building which has existed since 1735 have been successfully reproduced, with a variation of $3.5 \mathrm{~mm}$ accuracy. The point cloud is invaluable for this case study because there is no ambiguity at all. This effort has simultaneously produced 2D drawings and 3D models successfully in a single work. By having data from laser scanning, it eliminates the need to have a frequent site visit, and the details of the building can be further explored from our workstation. 
The result of this digitalization process has contributed to the know-how and know-what, especially in the management of point clouds for the documentation of historic building. The case study consists of a symmetrical design with two floors. During the modelling process, it was found that the building has used variant types of component. For example, the variations of the column found are five (5) and are shown in Figure 12.

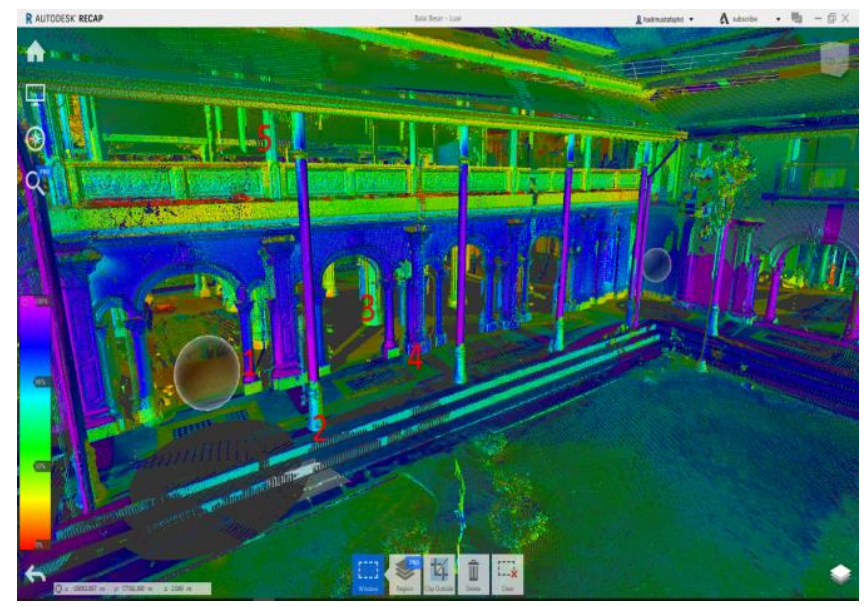

Figure 12: The numbers of column's variant found using point clouds for Istana Balai Besar (Author's work)

This case is considered to be another parameter to understand the advantage of technologies via action-based research. As another contribution from this action based-research activity, it can be extracted that the ground floor area of the building is approximately $2341 \mathrm{~m} 2$ and the first-floor area is $1341 \mathrm{~m} 2$ as shown in Figure 13 and Figure 14. The information can serve as the basis for further research to understand the profitability and benefits involved in using TLS for historic buildings in all regards.

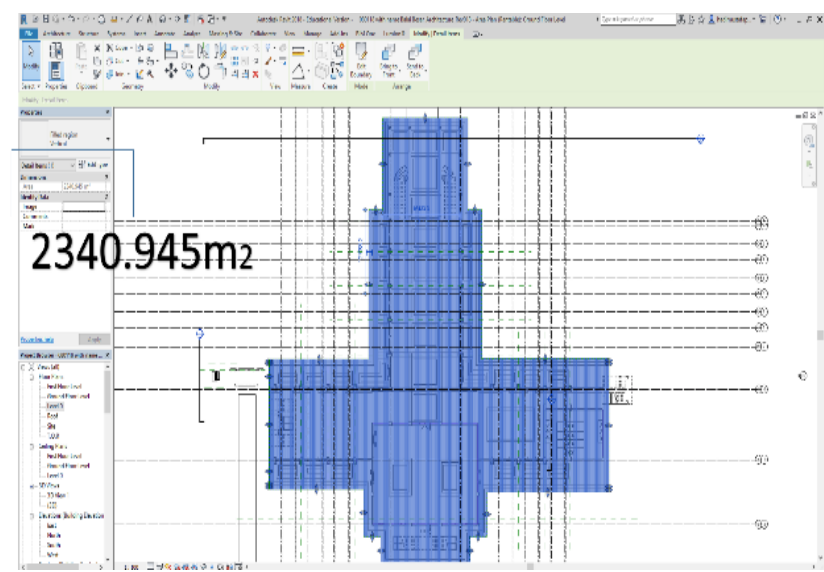

Figure 13: The extraction of Balai Besar Alor Setar's groundfloor layout area using BIM tool (Authors, 2019)

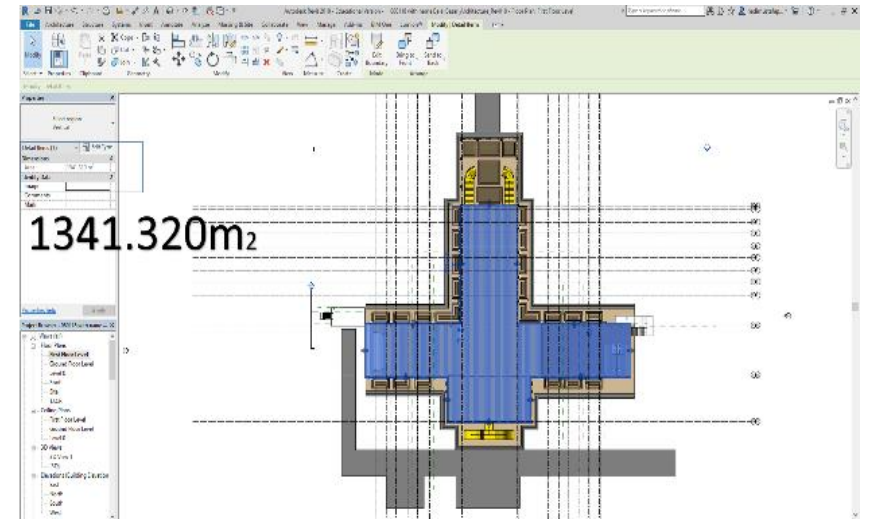

Figure 14: The extraction of Balai Besar Alor Setar's firstfloor layout area using BIM tool (Authors, 2019)

This research has provided a process flow on data collection using laser scanner and managing the data for the purpose of documenting the details of historic building. It is also found that there is still room for improvisation on this approach; for example, the automation from laser scanning into the BIM model. Terrestrial laser scanner also has difficulty in capturing high rise building, but this is not a major problem since the point cloud can be obtained with the help of laser scanning using an Unmanned Aerial Vehicle (UAV) such as the drones. At the current state of development, it is not possible to directly convert point clouds into a BIM model as it only acts as references. It is anticipated future development might focus on producing the BIM model straight away from their main references without the need to remodel them again manually in other software.

\subsection{Conclusion and Recommendations}

BIM has become an integral part of the way for new businesses, and it can be seen that greater client engagement is possible with the use of these technologies. The ability to have visual access to information through 3D illustrations without having to be on the site is deemed to be a ground-breaking process in AEC. Point cloud surveying is although a rapid process but the programming of the modelling need to be understood, managed and discussed with other parties who will rely on the information. The ability to produce accurate building information now forms a core part of our construction industry. From this research, it can be concluded that laser scanning is an effective approach to producing plans and elevations for any buildings, especially for historic buildings due to the reduced time on-site as compared with the conventional approach. Embracing BIM is not anymore about adapting to the local government's vision and mandate, it is more about recognizing the potential to become more efficient and effective in the operation and to compete effectively on the international level. Lastly, this research would like to suggest for heritageenthusiast in practicing their undertakings by:

i. Organizing appropriate and adequate training service on modelling of historical buildings, as simple methods 
need to be developed to obtain BIM models that guarantee accuracy, accuracy and quality at the same time.

ii. Integrating BIM with current historical buildings database within the conservation practice, which still is documented in a conventional approach.

iii. Encouraging young employees to possess competencies and qualities in utilizing technologies to increase the productivity and efficiency of their practice.

\section{Acknowledgements}

This research was supported by a grant (TRGS/1/2016/UIAM/01/5/3) from the Ministry of Higher Education Malaysia (MOHE). This research is also supported by Kuliyyah of Architecture and Environmental Design (KAED) and Kuliyyah of Engineering of International Islamic University Malaysia.

\section{References}

Abbasnejad, B., \& Moud, H. I. (2013). BIM and Basic Challenges Associated With Its Definitions, Interpretations, And Expectations. International Journal of Engineering Research and Application. 3(2): 287-294.

Abidin, W.B.b.W. (1981). The Malay House: Rationale and Change (Master Thesis). M.I.T., Massachusetts. Cambridge.

Akadiri, P. O., Chinyio, E. A., \& Olomolaiye, P. O. (2012). Design of A Sustainable Building: A Conceptual Framework for Implementing Sustainability in the Building Sector. 126-152. https://doi.org/10.3390/buildings2020126

Ali, M., Ismail, K., Suhaimi, M.S, Hashim, K.S.H.Y, and Mustafa, M.H., (2018), Heritage Building Preservation through Building Information Modelling: Reviving Cultural Values through Level Of Development Exploration. Journal of the Malaysian Institute of Planners. 16(2): 62 -72, http://dx.doi.org/10.21837/pmjournal.v16.i6.461

Ali, M., Ismail, K., Hashim, K.S.H.Y, Suhaimi, M.S, and Mustafa, M.H., (2018), Historic Building Information Modelling (HBIM) For Malaysian Construction Industry, Journal of the Malaysian Institute of Planners. $\quad$ 16(3): 332-343. http://dx.doi.org/10.21837/pmjournal.v16.i7.522

Autodesk. (2019). Autodesk Knowledge Network. Accessed 18.08.2019, from https://knowledge.autodesk.com: https://knowledge.autodesk.com/support/revit-products/gettingstarted/caas/CloudHelp/cloudhelp/2019/ENU/RevitGetStarted/files/GUID-03565843-BB48-4707-B54C-39D6E8E51880htm.html

Baik, A., Alitany, A., Boehm, J., \& Robson, S. (2014). Jeddah Historical Building Information Modelling "JHBIM"; Object Library. ISPRS Annals of Photogrammetry, Remote Sensing, and Spatial Information Sciences. II-5(May): 41-47. https://doi.org/10.5194/isprsannals-II-5-41-2014
Baik, A. (2017). From point cloud to Jeddah Heritage BIM Nasif Historical House - case study. Digital Applications in Archaeology and Cultural Heritage. 4(January 2016): 1-18. https://doi.org/10.1016/j.daach.2017.02.001

Del Giudice, M., \& Osello, A. (2013, September). BIM for Cultural Heritage. XXIV International CIPA Symposium. September 2-6, 2013, Strasbourg, France.

Bicara Seni Visual. (2014). Seni Bina Melayu Tradisional. Accessed 18.4.2020, from bicarasenivisual.blogspot.com: http:/ /bicarasenivisual.blogspot.com/2014/09/seni-bina-rumahmelayu-tradisional.html

Eastman, C. Teicholz, P. Sacks, R., \& Liston, K. (2008). BIM Handbook A Guide to Building Information Modeling for Owners, Managers, Designers, Engineers, and Contractors. John Wiley \& Sons, Inc.

Endut, E. H. (1993). Traditional Malaysian Built Forms: A Study of the Origins, Main Building Types, Development of Building Forms, Design Principles and the Application of Traditional Concepts in Modern Buildings. University of Sheffield.

Foxe D.M. (2010). Building Information Modeling for Constructing the past and its Future. Apt Bulletin: Journal Of Preservation Technology. 41(4): $39-45$

Fielden, B. M. (2003). Conservation Of Historic Buildings. 3rd ed. Oxford: Elsevier.

Harun, S. N. (2011). Heritage Building Conservation In Malaysia: Experience And Challenges. Procedia Engineering. 20: 41-53. https://doi.org/10.1016/j.proeng.2011.11.137

Taman Botani Negara Shah Alam. (2019). Kampung Idaman. Accessed 18.08.2019, from www.tbnsa.gov.my: http://www.tbnsa.gov.my/web/guest/kampung-idaman

MaiSinggah. (2018). 49 Bangunan Bersejarah Di Malaysia Yang Menarik | Jom Pulang Ke Masa Lampau. Accessed 18.08.2019, from www.maisinggah.com: https://www.maisinggah.com/bangunanbersejarah-di-malaysia/

Kawulich B. (2012): Doing Social Research: A Global Context Chapter: Collecting Data Through Observation Publisher. McGraw HillEditors: C. Wagner, B. Kawulich, M. Garner

Ismail, S. A., Bandi, S., \& Maaz, Z. N. (2018). An Appraisal into the Potential Application of Big Data in the Construction Industry. International Journal of Built Environment and Sustainability. 5(2): 145-154. https://doi.org/10.11113/ijbes.v5.n2.274

Rahman, M. F. (2003). Laluan Tempt Bersejarah di Bandar Alor Setar: Bangunan-Bangunan Bersejarah. Alor Setar: Arkib Negara Malaysia Cawangan Kedah.Retrieved July 2018

Malaysia Building Information Modelling Report (2016), CIDB Technical report Publication No 1217, Lembaga Pembangunan Industri Pembinaan Malaysia, Kuala Lumpur. 2017

Maina, J. J. (2018). Barriers To Effective Use Of CAD And BIM In Architecture Education In Nigeria. International Journal of Built Environment 
and Sustainability. $\quad$ 5(3): 175-186.

https: / / doi.org/10.11113/ijbes.v5.n3.275

Mustafa, M.H., Ali, M., Ismail, K., Hashim, K.S.H.Y, and Suhaimi, M.S. (2019). BIM Backed Decision Support System in the Management of Heritage Building. International Journal of Built Environment and Sustainability. 6(2): 63-71. https: //doi.org/10.11113/ijbes.v6.n2.357

Jabatan Warisan Negara, 2016, National Heritage Act 645, accessed online (Accessed

18.08.2019) http://www.heritage.gov.my/index.php/ms/2016-06-1402-33-04

Pesci, A., Bonali, E., Galli, C., \& Boschi, E. (2012). Laser scanning and digital imaging for the investigation of an ancient building: Palazzo d'Accursio study case (Bologna, Italy). Journal of Cultural Heritage. 13(2): 215-220. https://doi.org/10.1016/j.culher.2011.09.004

Quattrini, R., Malinverni, E. S., Clini, P., Nespeca, R., \& Orlietti, E. (2015). From TLS to HBIM. High-quality semantically-aware $3 \mathrm{~d}$ modelling of complex architecture. International Archives of the Photogrammetry, Remote Sensing and Spatial Information Sciences - ISPRS Archive., 40(5W4): 367-374. https://doi.org/10.5194/isprsarchivesXL-5-W4-367-2015
Rozana Mohamed Salleh, N. E. M., Nafisah Abdul Rahiman, H., \& Liyana Tajul Ariffin, N. O. (2019). The Propensity Of Building Information Modelling And Integrated Project Delivery In Building Construction Project. International Journal of Built Environment \& Sustainability. 6(1-2): 83-90. https://doi.org/10.11113/ ijbes.v6.n12.386

Seghier, T. E., Lim, Y. W., Ahmad, M. H., \& Samuel, W. O. (2017). Building Envelope Thermal Performance Assessment Using Visual Programming and BIM, based on ETTV requirement of Green Mark and GreenRE. International Journal of Built Environment and Sustainability. 4(3), 227-235. https://doi.org/10.11113/ijbes.v4.n3.216

W. Kymmel (2008), Building Information Modeling. Planning and managing construction projects with 4D CAD and simulations, McGrawHill.

Zahrizan, Z., Ali, N. M., Haron, A. T., Marshall-Ponting, A., \& Hamid, Z. A. (2013). Exploring The Barriers And Driving Factors In Implementing Building Information Modelling (BIM) In The Malaysian Construction Industry: A Preliminary Study. Journal - The Institution of Engineers, Malaysia. 75(1):1- 10. 